\title{
RELATIONSHIP BETWEEN STUDENT LEARNING ENVIRONMENT, HOW TO LEARN AND LEARN MOTIVATION WITH RESULTS OF MATHEMATICS STUDENTS IN CLASS VIII SMP NEGERI 2 PLERET
}

\author{
Kurnia Prantauwati ${ }^{\mathrm{a}}$, Aris Thobirin ${ }^{\mathrm{b}}$ \\ Program Studi Pendidikan Matematika Universitas Ahmad Dahlan \\ Jalan Ring Road Selatan, Tamanan, Banguntapan, Bantul Yogyakarta \\ anniaahmadi12@gmail.com, baris.thobi@math.uad.ac.id
}

\begin{abstract}
Based on the information from the students of SMP Negeri 2 Pleret Bantul District, students are less conducive to the learning environment, as well as learning styles about students' learning motivation is low. This study aims to determine whether there is a positive and significant relationship between students' learning environment, learning style and learning motivation the mathematics learning outcomes of class VIII SMP Negeri 2 Pleret Bantul District in the odd semester in the academic year of 2016/2017. The population of the research is all student's regular classes VIII of SMP Negeri 2 Pleret Bantul District of the odd semester in the academic year of 2016/2017 as many as 7 classes. Taken as a class VIII G class research sample by random sampling technique to class. Data collection techniques such as questionnaires and test engineering. Questionnaire research instrument for the variables of students' learning environment, variable learning style, and variable learning motivation while research instrument outcome variables studied mathematics. Test using a research instrument validity, different power, and reliability testing. Analysis prerequisite test including normality test, independent test and linearity test. Data analysis for hypothesis testing using product-moment correlation analysis and multiple linear regression analysis. The results showed a positive and significant relationship between (1) the learning environment of students with mathematics learning outcomes, with $\mathrm{R}=0.4317$; (2) learning style with mathematics learning outcomes, with $\mathrm{R}=0.5145$; (3) learning motivation with mathematics learning outcomes, with $\mathrm{R}=0.4012$; (4) the learning environment of students and learning style with mathematics learning outcomes, with $R=0.5728$; (5) students' learning environment and learning motivation with mathematics learning outcomes, with $\mathrm{R}=$ 0.4632 ; (6) learning style and learning motivation with mathematics learning outcomes, with $\mathrm{R}=$ 0.5725 ; (7) the learning environment of students, learning style and learning motivation with mathematics learning outcomes, with $\mathrm{R}=0.5874$ and the linear regression equation $\hat{Y}=-60,3895+$ $0,2665 X_{1}+0,8747 X_{2}+0,5304 X_{3}$. Large donations are relatively $X_{1}=21,7776 \%, X_{2}=58,7420 \%$ and $X_{3}=19,4804 \%$ and the effective contribution $X_{1}=7,5134 \%, X_{2}=20,2664 \%$ and $X_{3}=6,7209 \%$. This shows that the way of learning style $\left(\mathrm{x}_{2}\right)$ have a greater relationship to mathematics learning outcomes.
\end{abstract}

Keywords: students learning environment, learning style, learning motivation, Learning Outcomes,

\section{INTRODUCTION}

One effort to realize national ideals and goals can be done through improving the quality of education. Education is the basic capital in shaping mindset and intellectual development, education is also a means of continuing values, ideas and perfecting ways of thinking (Moh. Hamzah, Ismail, 2009: 102). Education, among others, is carried out through learning activities organized by educational institutions. Learning activities are the efforts of educational institutions to influence students to achieve quality which is the goal of educational institutions. To achieve this quality, learning activities are carried out through both direct and indirect interactions between educators and students.

Hudojo (in Hasratuddin, 2014: 30) states that: "Mathematics is abstract ideas that are given hierarchically arranged symbols and deductive reasoning, so learning mathematics is a high mental activity. "Whereas according to James in his mathematical dictionary states that" Mathematics is the science of logic regarding the form, composition, quantity and other related concepts with a large number which is divided into three fields, namely algebra, analysis, and geometry.

In the learning process, the environment is a factor that influences student learning outcomes and learning processes. The condition of a conducive learning environment at home will create the 
calmness and comfort of students in learning, so students will find it easier to master learning material to the fullest. Based on information from a number of students of SMP Negeri 2 Pleret, Bantul Regency, the learning environment at home of students is less comfortable being used for learning. So students prefer watching television rather than studying, or prefer to play with friends. Parents do not provide maximum learning assistance if students are at home. The results of interviews with some VII grade students said that their parents were busy working, so they paid less attention to student learning and rarely asked for assignments or not from school. In addition to environmental learning factors at home, there are several factors that are thought to influence learning outcomes, one of which is how to learn. How to learn is a way how students carry out learning activities such as how they prepare to learn, take lessons, independent learning activities undertaken, their learning patterns, how to take the exam (Mappeasse, Muh. Yusuf, 2009). Based on information from students, most students do not have a good way of learning. Students claim to be less prepared in following the lessons, so students lack focus in following the lessons and lack of independent learning activities undertaken by students.

In addition to learning, another factor that is thought to influence learning outcomes is learning motivation. Hamalik (in Mappeasse, Muh. Yusuf, 2009) Motivation is a condition in an individual that causes a person to carry out certain activities to achieve goals. To be able to learn well, students must have high motivation, so the possibility of mistakes in learning theory or practice can be reduced, thus the student is able to do the task well. Based on the results of interviews with some eighth-grade students, most students do not yet have high enthusiasm and motivation in learning, students tend to be lazy to listen and pay attention to the lessons delivered by the teacher during the learning process. According to Fitri, Rahma (2014: 9) learning outcomes are mastery achieved by students after participating in the learning process. Learning outcomes obtained by students from an activity that results in changes in behavior expressed by scores/values obtained from learning outcomes tests. The low mathematics learning outcomes of Grade VIII students of SMP Negeri 2 Pleret, Bantul Regency, can be seen from the average value of mathematics at the end of the semester exam which is still low. The final semester mathematics grade scores of SMP Negeri 2 Pleret Bantul Regency are $84.40 \%$ below the KKM standard. This proves that there are still many students who have difficulty in learning mathematics.

Based on the background and boundaries of the problem, it can be formulated the problem to be investigated, namely is there a positive and significant relationship between student learning environments, ways of learning and learning motivation with mathematics learning outcomes of students of class VIII of SMP Negeri 2 Pleret, Bantul Regency, odd semester 2016/2017 school year?

The aim of this research is to find out whether or not there is a positive and significant relationship between students' learning environments, ways of learning and learning motivation with mathematics learning outcomes of Grade VIII students of SMP Negeri 2 Pleret Bantul Regency in the odd semester of the 2016/2017 school year?

\section{METHODS}

This research is classified as quantitative research. The place of research was conducted at SMP Negeri 2 Pleret, Bantul Regency. While the time of the study was conducted in the odd semester of the 2016/2017 school year. As for the population in this study, all students of class VIII of the odd semester of SMP Negeri 2 Pleret, Bantul Regency consisted of 7 classes, all of which were homogeneous, because classes were arranged randomly without leading classes. In this study, samples were taken at random using a random sampling technique for class. It is said random because the sample class taking is done randomly from the existing class because the ability of each class in the population is the same and the sample class taken is VIIIG with 30 students. The research variables are two variables, they are the independent variable and the dependent variable. The independent variable (Independent) consists of student learning environment $\left(\mathrm{X}_{1}\right)$, way of learning $\left(\mathrm{X}_{2}\right)$ and motivation to learn $\left(\mathrm{X}_{3}\right)$, while the dependent variable (dependent) is the result of learning mathematics (Y). Data collection techniques used questionnaires and test methods. In this study, the questionnaire method was used to obtain data on 
student learning environments, ways of learning and student motivation. While the test method is used to obtain data on mathematics learning outcomes for students of class VIII SMP Negeri 2 Pleret, Bantul Regency. The questionnaire test uses the content validity test by reviewers and the instrument reliability test with the alpha formula, while the test instrument questions use the instrument validity test with product-moment correlation techniques, different power tests and instrument reliability tests with the KR-20 formula (Suharsimi Arikunto. 2013: 115 ). After the data is collected, the analysis prerequisite tests that must be met include normality test, linearity test, and independent test. Data analysis uses product-moment correlation analysis and multiple linear regression analysis.

\section{RESULTS AND DISCUSSION}

In this section further discussion of the results of research analyzed in correlation. This study found that the seventh hypothesis test results were that there was a positive and significant relationship between student learning environments, ways of learning and students' motivation to learn mathematics. In other words, the better the student's learning environment, the better the learning outcomes. Likewise with the way to learn, the better the way of learning by students, the better the learning outcomes obtained. In addition, learning motivation also affects learning outcomes, because if learning motivation is high then the learning outcomes will also be higher. In this study also uses analysis prerequisite tests which include:

1. Normality Test

This normality test is used to test the distribution of data obtained by each variable whether it is normally distributed or not. The summary of the normality test results from the four variables are:

Table 1. Summary of the normality test

\begin{tabular}{|l|l|l|l|l|l|}
\hline No & \multicolumn{1}{|c|}{ Variable } & $\boldsymbol{\chi}_{\text {count }}^{\mathbf{2}}$ & $\boldsymbol{\chi}_{\text {table }}^{\mathbf{2}}$ & $\mathbf{D f}$ & Info \\
\hline 1 & Student learning environment $\left(X_{1}\right)$ & 1,0381 & 5,9910 & 2 & Normal \\
\hline 2 & How to learn $\left(X_{2}\right)$ & 3,7656 & 5,9910 & 2 & Normal \\
\hline 3 & Motivation to learn $\left(X_{3}\right)$ & 2,5646 & 5,9910 & 2 & Normal \\
\hline 4 & Mathematical Learning Outcomes $(Y)$ & 0,2778 & 7,8147 & 3 & Normal \\
\hline
\end{tabular}

2. Independence Test

Independence test is used to find out whether or not there is a relationship between independent variables. A summary of the results of the independent tests of the three independent variables is:

Table 2. Summary of Independence test

\begin{tabular}{|c|c|c|c|c|c|}
\hline No & Variable & $\boldsymbol{\chi}_{\text {count }}^{\mathbf{2}}$ & $\boldsymbol{\chi}_{\text {table }}^{\mathbf{2}}$ & Df & Info \\
\hline 1 & $X_{1}$ to $X_{2}$ & 337,135 & 337,625 & 25 & Independent \\
\hline 2 & $X_{1}$ to $X_{3}$ & 333,608 & 337,625 & 25 & Independent \\
\hline 3 & $X_{2}$ to $X_{3}$ & 228,469 & 337,625 & 25 & Independent \\
\hline
\end{tabular}

3. Linearity Test

Linearity test is used to find out between independent variables and dependent variables whether they have a linear relationship or not. Summary of the linearity test results of the four variables are:

Table 3. Summary of Linearity test

\begin{tabular}{|l|l|c|c|l|}
\hline No & Variable & $\boldsymbol{F}_{\text {count }}$ & $\boldsymbol{F}_{\text {table }}$ & Info. \\
\hline 1 & $X_{1}$ to $Y$ & 0,6102 & 2,6851 & Linear \\
\hline 2 & $X_{2}$ to $Y$ & 0,9782 & 2,5331 & Linear \\
\hline 3 & $X_{3}$ to $Y$ & 0,5255 & 2,5331 & Linear \\
\hline
\end{tabular}


4. Hypothesis Testing

From the multiple correlation analysis, it is obtained the value of the multiple correlation coefficient $(\mathrm{R})$ of 0.5874 . In this study also obtained a coefficient of determination $\left(R^{2}\right)$ of 0.3450 meaning $34.50 \%$ of learning outcomes are influenced by student learning environment, ways of learning and learning motivation while the rest is influenced by other factors. There is a variance in mathematics learning outcomes (Y) that can be explained by the student learning environment $\left(\mathrm{X}_{1}\right)$, ways of learning $\left(\mathrm{X}_{2}\right)$, and learning motivation $\left(X_{3}\right)$ through linear lines $\hat{Y}=$ $-60,3895+0,2665 X_{1}+0,8747 X_{2}+0,5304 X_{3}$. This means an increase in one unit $\left(\mathrm{X}_{1}\right)$ resulted in 0.2665 increase in $\mathrm{Y}$, an increase in one unit $\left(\mathrm{X}_{2}\right)$ resulted in 0.8747 increase in $\mathrm{Y}$, and wearing one unit $\left(X_{3}\right)$ resulted in a 0.5304 increase in $\mathrm{Y}$. While for the relative magnitude of contribution $\left(\mathrm{X}_{1}\right)=21,7776 \%,\left(\mathrm{X}_{2}\right)=58.7420 \%$ and $\left(X_{3}\right)=19.4804 \%$ and effective contributions $\left(X_{1}\right)=7.5134 \%,\left(X_{2}\right)=20.2664 \%$ and $\left(X_{3}\right)=6.7209 \%$. This shows that the way of learning $\left(\mathrm{X}_{2}\right)$ has a more significant relationship to the learning outcomes of mathematics compared to the student learning environment and learning motivation.

\section{CONCLUSION}

Based on the results of research and discussion as described above, it can be concluded that there is a positive and significant relationship between student learning environments, ways of learning and learning motivation with mathematics learning outcomes of eighth grade students of SMP Negeri 2 Pleret Bantul Regency in the odd semester of the 2016 school year /2017. This is indicated by the - F test is $F_{\text {count }}>F_{\text {table }}$ or $4,5650>2,9800$ with a double correlation coefficient (R) of 0.5874 and a coefficient of determination $\left(R^{2}\right)$ of 0.3450 . Linear regression equation $\hat{Y}=-60,3895+0,2665 X_{1}+$ $0,8747 X_{2}+0,5304 X_{3}$. The relative contribution of $X_{1}$ is $21.7776 \%, X_{2}$ is $58.7420 \%$ and $X_{3}$ is $19.4804 \%$ and the effective contribution of $X_{1}$ is $7.5134 \%, X_{2}$ is $20.2664 \%$ and $X_{3}$ is $6.7209 \%$.

\section{REFRENCES}

Arikunto, Suharsimi. 2013. Dasar-dasar Evaluasi Pendidikan. Jakarta: Bumi Aksara.

Fitri, Rahma, dkk. 2014. Penerapan Strategi The Firing Line Pembelajaran Matematika siswa Kelas XI IPS SMA Negeri 1 Batipuh. Jurnal Pendidikan Matematika vol.3 No.1.

Hasratuddin. 2014. Pembelajaran Matematika Sekarang dan yang akan Datang Berbasis karakter. Jurnal Didaktik Matematika Vol. 1, No. 2.

Khasanah, Uswatun. 2013. Analisis Regresi. Yogyakarta: MIPA UAD Press.

Mappeasse, Muh. Yusuf. 2009. Pengaruh Cara dan Motivasi Belajar Terhadap Hasil Belajar Programmable Logic Controller (PLC) Siswa Kelas III Jurusan Listrik SMK Negeri 5 Makssar. Jurnal MEDTEK Vol.1 No. 2.

Moh.Hamzah, Ismail. 2009. Pengaruh Lingkungan dan Motivasi Belajar Siswa Terhadap Hasil Belajar Matematika Siswa di Kejar Paket C PKBM Sultan Agung Kesambi Kota Cirebon .EduMa, Vol. 1, No. 2.

Sugiyono. 2015. Metodologi Penelitian Pendidikan.Bandung:Alfabeta.

Suparman. 2015. Metodologi Penelitian Pendidikan. Yogyakarta: MIPA UAD Press. 